\title{
GESTIÓN HÍDRICA EN EL SISTEMA FAMILIAR LÁCTEO DE LA SUBCUENCA AMECAMECA EN EL ESTADO DE MÉXICO
}

\author{
WATER MANAGEMENT IN THE FAMILY DIARY SYSTEM IN THE SUB-BASIN OF \\ AMECAMECA, ESTADO DE MÉXICO
}

\author{
Laura D. Rueda-Quiroz ${ }^{1}$, Luis Brunett-Pérez ${ }^{2 *}$, Enrique Espinosa-Ayala ${ }^{2}$, Tizbe T. Arteaga-Reyes \\ ${ }^{1}$ Ciencias Agropecuarias y Recursos Naturales. Universidad Autónoma del Estado de México. \\ Juchitepec, México. 56860. (zidfenril@yahoo.com.mx) ${ }^{2}$ Centro Universitario UAEM Amecameca. \\ Universidad Autónoma del Estado de México. Carretera Amecameca Ayapango Km. 2.5 \\ Amecameca, México. 56900. (lbrunettp@uaemex.mx) (enresaya1@hotmail.com) 3nstituto de \\ Ciencias Agropecuaria y Rurales. Universidad Autónoma del Estado de México. Km 14.5 Carretera \\ Toluca-Atlacomulco, San Cayetano, Toluca, México. 50295. (ttarteagar@uaemex.mx)
}

\section{RESUMEN}

El objetivo de esta investigación fue analizar la gestión hídrica en el sistema familiar lácteo en la subcuenca Amecameca, del Estadp de México. El enfoque teórico se derivó de la propuesta GIRH (Gestión Integrada del Recurso Hídrico). El trabajo de campo se llevó a cabo de septiembre a diciembre de 2012. La muestra de productores fue de 22 unidades de producción. En cuanto a los actores sociales, se seleccionaron seis informantes clave de diversas dependencias de los niveles federal, estatal y municipal. El análisis se realizó mediante estadística descriptiva. Los resultados muestran que el costo anual promedio por pago de agua fue de $\$ 2920.00$ pesos mexicanos (incluye toma municipal y camión cisterna). El agua proviene de seis pozos y cuatro sistemas de deshielos (arroyos). En cuanto a la producción de leche, se requieren 6.6 1 de agua (incluye consumo y servicio de limpieza) en promedio para producir un litro de leche. Por tanto, el sistema es parcialmente ineficiente en el consumo de agua de bebida (5.61 de agua por litro de leche) si se compara con otros resultados reportados. A pesar de ello, el sistema genera una presión hídrica mínima (2.2\%) sobre el volumen de agua concesionada en la zona. La información obtenida permite concluir que no hay un problema de escasez en el volumen de agua concesionada, sino una problemática social de distribución del recurso.

Palabras clave: conversión agua-leche, gestión del agua, producción de leche.

\footnotetext{
* Autor responsable * Author for correspondence.

Recibido: diciembre, 2013. Aprobado: enero, 2015.

Publicado como ARTÍCULO en ASyD 12: 165-179. 2015.
}

\begin{abstract}
The objective of this study was to analyze water management in the Amecameca Sub-Basin family dairy system, in the State of México. The theoretic approach was derived from IWRM (Integrated Water Resources Management). The field work took place from September to December, 2012. The sample of producers was 22 production units. In terms of the social actors, six key informants were selected from various offices in the federal, state and municipal levels. The analysis was carried out through descriptive statistics. Results show that the average annual cost per water payment was $\$ 2920.00$ Mexican pesos (including the municipal tap and tank trucks). The water comes from six wells and four ice-melt systems (streams). With regard to milk production, 6.61 of water are required (including for consumption and cleaning services), in average, to produce one liter of milk. Therefore, the system is partially inefficient in terms of drinking water consumption (5.61 of water per liter of milk), when compared to other results reported. In spite of this, the system generates a minimal hydric pressure $(2.2 \%)$ on the volume of water allotted in the area. The information obtained allows concluding that there is not a problem of scarcity in the volume of water assigned, but rather a social problem of distribution of the resoruce.
\end{abstract}

Key words: water-milk conversion, water management, milk production.

\section{INTRODUCTION}

A t the global level society faces a growing crisis regarding natural resources, primarily water scarcity and contamination, as well as changes in the hydrologic cycle (UNESCO, 2010). Therefore, in recent years the water resource has 


\section{INTRODUCCIÓN}

$\mathrm{A}$ nivel mundial la sociedad enfrenta una creciente crisis sobre los recursos naturales, principalmente escasez y contaminación de agua, así como modificaciones en el ciclo hidrológico (UNESCO, 2010). Por tanto, en los últimos años el recurso hídrico ha sido el tema central en la agenda de muchos países (Carbajal et al., 2011). En 1992, en la Conferencia Internacional sobre Agua y Medio Ambiente, se crearon los principios de Dublín, a partir de los cuales se fundamenta el enfoque de Gestión Integrada de los Recursos Hídricos (GWP, 2003). En 2002 se realizó la Cumbre sobre Desarrollo Sostenible, en la cual se instó a los países del mundo a crear planes de gestión de sus recursos hídricos (GWP, 2008).

Ante la problemática hídrica global surge una estrategia que da margen a la creación de planes sobre una mejor administración del recurso, llamada Gestión Integrada de los Recurso Hídricos (GIRH), la cual fue creada por la Asociación Mundial para el Agua y la Red Internacional de Organismo de Cuenca (GWP-INBO, 2009).

En este contexto, Berghuber et al. (2010) mencionan que la gestión del agua está estrechamente ligada con el conocimiento práctico de una comunidad para satisfacer las necesidades hídricas que tiene. Steiner (1998) señala que la gestión es la administración de cualquier recurso, y se lleva a cabo a través de un proceso coordinado que busca lograr los objetivos organizacionales establecidos de forma eficaz a través de sus distintas fases (planeación, organización, dirección y control). Soares (2007) señala que, debido a la creciente conflictividad social en torno al agua, se debe reconocer al recurso hídrico desde otra perspectiva, no solo como un bien público con el que cuenta la sociedad, sino desde un enfoque económico, dándole el valor que en verdad tiene el recurso para que, a partir de esta perspectiva, se generen políticas públicas alrededor de este recurso. Aguilar (2009), menciona que el recurso agua tiene valor en sí mismo, pero se debe tener cuidado con la naturaleza de ese precio, ya que el costo social es indiscutible y el económico innegable. Según Solanes y González (1996), el valor del agua depende del uso o servicio que se esté haciendo del recurso (doméstico, industrial, agrícola), así como de la valoración como un recurso become the central theme in the agenda of many countries (Carbajal et al., 2011). In 1992, during the International Conference on Water and the Environment, the Dublin principles were created, upon which the approach of Integrated Water Resources Management is based (GWP, 2003). In 2002, the Summit on Sustainable Development was carried out, where the countries of the world were urged to create management plans for their water resources (GWP, 2008).

In face of the global water problematic, a strategy has arisen that gives way to the creation of plans for a better administration of the resource, and it is called Integrated Water Resources Management (IWRM), which was created by the World Association for Water and the International Network of Basin Organizations (GWP-INBO, 2009).

Within this context, Berghuber et al. (2010) mention that water management is closely linked to the practical knowledge of a community to satisfy its water needs. Steiner (1998) points out that management is the administration of any resource and that it takes place through a coordinated process that seeks to achieve the organizational objectives established, in an efficient manner, through its different phases (planning, organization, direction and control). Soares (2007) mentions that, due to the growing social conflict around water, the water resource should be recognized from a different perspective, not only as a public good that society has access to, but rather from an economic approach, giving it the value that the resource really has, so that public policies can be generated around this vital resource from this perspective. In turn, Aguilar (2009) points out that the water resource has a value in itself, but there should be precaution with the nature of this price, since the social cost is indisputable and the economic one undeniable. According to Solanes and González (1996), the value of water depends on the use or service that is being made (domestic, industrial, agricultural), as well as its valuation as an environmental and economic public resource; however, having been considered as an abundant resource for a long time, the mistaken idea that it is a free good is maintained.

In 2006, the $4^{\text {th }}$ World Water Forum took place in Mexico City, where the commitment of achieving the goals directed at implementing the Integrated Water Resources Management was reaffirmed 
público ambiental y económico; sin embargo, al ser considerado durante mucho tiempo como un recurso abundante, se mantiene la idea errónea de que es un bien gratuito.

En 2006 se llevó a cabo el IV Foro Mundial del Agua en la Ciudad de México, donde se reafirmó el compromiso de lograr las metas orientadas a la implementación de la Gestión Integrada de los Recursos Hídricos (CONAGUA, 2006). En México se formuló el Programa Nacional Hídrico 2014-2018, donde se plantearon las nuevas formas de políticas hídricas y de gestión del recurso (CONAGUA, 2014).

El panorama del agua en México es preocupante, por lo que el gobierno de la República lo reconoce como un asunto de seguridad nacional. Carabias y Landa (2005) enfatizan que la crisis del agua pone en riesgo el desarrollo que pudiera tener el país en los próximos años.

A nivel local, en la Región Hidrológica No. XIII "Aguas del Valle de México" existe un panorama similar. Ésta ha sido clasificada como una región con escasez hídrica absoluta y con acuíferos sobreexplotados, como es el de Chalco-Amecameca (CONAGUA, 2009), cuyos usos de agua por volumen extraído destacan: público urbano $83.7 \%$; público urbano sin concesión, $10.3 \%$; industrial, $2.6 \%$; y agrícola, $3.4 \%$, con una distribución promedio de agua de 139 1/habitante/día en los municipios de Ayapango y Amecameca (Burns, 2009). En 2012 la tarifa bimestral por toma (13 milímetros) de interés social y popular fue de 2.17 salarios mínimos, considerando un costo por salario de $\$ 59.00$ para ese ańo (Gaceta del Gobierno del Estado de México, 2012). En el mismo año los Gobiernos Federal y Estatal pusieron en marcha el proyecto "Programa de Saneamiento Integral de la Parte Alta de la Cuenca del Río Amecameca", cuyo objetivo es la construcción de seis plantas de tratamiento de aguas residuales en diferentes municipios de la Subcuenca (SEMARNAT-CONAGUA, 2012). Ante este panorama el problema del agua es realmente preocupante, más aún en las comunidades rurales, tanto en su abundancia por ocasionar desastres naturales como por su escasez, debido a las prácticas agrícolas y ganaderas de los productores (Villanueva, 2008).

Uno de los sectores productivos de la sociedad rural es la actividad ganadera, en específico la lechera. Steinfeld et al. (2009) mencionan que el consumo de agua por la ganadería contribuye al agotamiento del
(CONAGUA, 2006). In México, the National Water Program 2014-2018 was formulated, where the new directions for water policies and resource management were set out (CONAGUA, 2014).

The water panorama in México is worrisome, so the government of the Republic recognizes it as an issue of national security. Carabias and Landa (2005) emphasize that the water crisis places at risk the development that the country could have in the coming years.

At the local level, in Hydrological Region Number 13 "Aguas del Valle de México", there is a similar panorama. It has been classified as a region with absolute water scarcity, and with overexploited aquifers, such as the one in Chalco-Amecameca (CONAGUA, 2009), whose water uses per volume extracted are: public urban $83.7 \%$; public urban without concession, $10.3 \%$; industrial, $2.6 \%$; and agricultural, $3.4 \%$, with an average water distribution of 139 1/inhabitant/day in the municipalities of Ayapango and Amecameca (Burns, 2009). In 2012, the bimonthly fee per tap (13 millimeters) of social and popular interest was 2.17 minimum wages, considering a cost per salary of $\$ 59.00$ for that year (Gaceta del Gobierno del Estado de México, 2012). During that same year, the Federal and State governments implemented the project "Integral Sanitation Program for the High Basin of the Amecameca River" (Programa de Saneamiento Integral de la Parte Alta de la Cuenca del Río Amecameca), whose objective is the construction of six residual treatment plants in different municipalities of the sub-basin (SEMARNAT-CONAGUA, 2012). In view of this panorama, the water problem is quite worrisome, particularly in rural communities, both for its abundance when causing natural disasters and for its scarcity, as a result of the agricultural and livestock production practices of producers (Villanueva, 2008).

One of the productive sectors of the rural society is livestock production, specifically dairy production. Steinfeld et al. (2009) mention that water consumption from livestock production contributes to the depletion of the water resource, at a high level and in constant growth, foreseeing that in the coming decades the livestock use will experience an increase of $50 \%$ in water utilization. FAO (2010) mentions that livestock production uses $8 \%$ of the liquid in the world. 
recurso hídrico a un nivel elevado y en constante crecimiento, pronosticando que en las próximas décadas el uso pecuario experimentará un aumento de $50 \%$ en la utilización del agua. La FAO (2010) menciona que la ganadería emplea $8 \%$ del líquido a nivel mundial.

Según Gallardo (2004), dentro del sistema de producción de leche en pequeña escala (SPLPE) o familiar los productores consideran a la actividad lechera como un complemento de la producción agrícola y cuentan con instalaciones rústicas dentro del establo. Estos sistemas cuentan con 3 a 20 vientres de bovino de leche con sus respectivos reemplazos. La superficie agrícola es propia, y en algunos casos se le renta a terceras personas (Espinosa, 2009). La SAGARPA (2000) reporta que el Sistema Familiar de Leche aporta 70 millones de litros de leche anuales a la producción nacional, representados por $9.4 \mathrm{del}$ total; de igual manera, SIAP (2006) menciona que este sistema aporta $9.8 \%$ a la producción del país y posee $18.9 \%$ de los vientres.

El objetivo en esta investigación fue analizar la gestión hídrica a través del enfoque GIRH en el sistema familiar lácteo en la Sub-cuenca Amecameca, Estado de México.

\section{Materiales y Métodos}

El estudio se realizó en la subcuenca Amecameca (Figura 1) en los municipios de Amecameca y Ayapango, situados al sur-oriente del Estado de México en las faldas de la Sierra Nevada, dentro de la provincia del eje volcánico y la cuenca del Río MoctezumaPánuco. El municipio de Amecameca se localiza entre las coordenadas geográficas $98^{\circ} 37^{\prime} 34^{\prime \prime}$ y $98^{\circ} 49^{\prime}$ $10^{\prime \prime} \mathrm{O}$ y $19^{\circ} 3^{\prime} 12^{\prime \prime}$ y $19^{\circ} 11^{\prime} 2^{\prime \prime} \mathrm{N}$, a una altura de 2420 metros sobre el nivel del mar; el clima es templado subhúmedo y registra una temperatura media anual de $14.1^{\circ} \mathrm{C}$. El municipio de Ayapango se localiza entre las coordenadas $19^{\circ} 11^{\prime} \mathrm{N}$ y $98^{\circ} 45^{\prime} \mathrm{O}$, a una altura de $2450 \mathrm{~m}$ y su clima es subhúmedo con lluvias en verano (IGECEM, 2011a). El trabajo de campo se realizó de septiembre a diciembre de 2012, ya que en esta temporada comienza una disminución en la disponibilidad o suministro de agua, a diferencia de la época de lluvias.

En esta investigación se aplicó la Metodología de Gestión Integrada de los Recursos Hídricos (GIRH) propuesta por la Global Water Partnership
According to Gallardo (2004), within the smallscale or family dairy production system (SSDPS) producers consider dairy activity as a complement to agricultural production and have rustic facilities within the barn. These systems have 3 to 20 heads of dairy breeding stock with their corresponding replacements. The agricultural surface belongs to them and in some cases they rent to third parties (Espinosa, 2009). SAGARPA (2000) reports that the Family Dairy System contributes 70 million liters of milk to the national production, represented by 9.4 of the total; likewise, SIAP (2006) mentions that this system contributes $9.8 \%$ to the country's production and owns $18.9 \%$ of the heads of breeding stock.

The objective in this research was to analyze water management through the IWRM approach in the Amecameca Sub-Basin family dairy system, State of México.

\section{Materials and Methods}

The study was performed in the Amecameca SubBasin (Figure 1), in the municipalities of Amecameca and Ayapango, located in the southeast of Estado de México on the skirts of Sierra Nevada, within the province of the volcanic axis and the MoctezumaPánuco River Basin. The municipality of Amecameca is located between geographic coordinates $98^{\circ} 37^{\prime}$ $34^{\prime \prime}$ and $98^{\circ} 49^{\prime} 10^{\prime \prime} \mathrm{W}$ and $19^{\circ} 3^{\prime} 12^{\prime \prime}$ and $19^{\circ} 11^{\prime} 2^{\prime \prime}$ $\mathrm{N}$, at an altitude of $2420 \mathrm{~m}$; the climate is temperate sub-humid and has a mean annual temperature of $14.1{ }^{\circ} \mathrm{C}$. The municipality of Ayapango is located between coordinates $19^{\circ} 11^{\prime} \mathrm{N}$ and $98^{\circ} 45^{\prime} \mathrm{W}$, at an altitude of $2450 \mathrm{~m}$ and its climate is sub-humid with summer rains (IGECEM, 2011a). The field work was performed from September to December 2012, since within this season there is a decrease in the water availability or supply, as opposed to the rainy season.

In this research, the methodology of Integrated Water Resources Management (IWRM), proposed by the Global Water Partnership-GWP (2008) and modified by Díaz et al. (2009), was applied, including a cycle of seven stages: (1) Beginning, (2) Vision, (3) Analysis, (4) Strategies, (5) Plan, (6) Implementation and (7) Evaluation. Taking into account that this methodology is focused primarily on sociopolitical aspects to establish plans that support public policies around water, in this study 


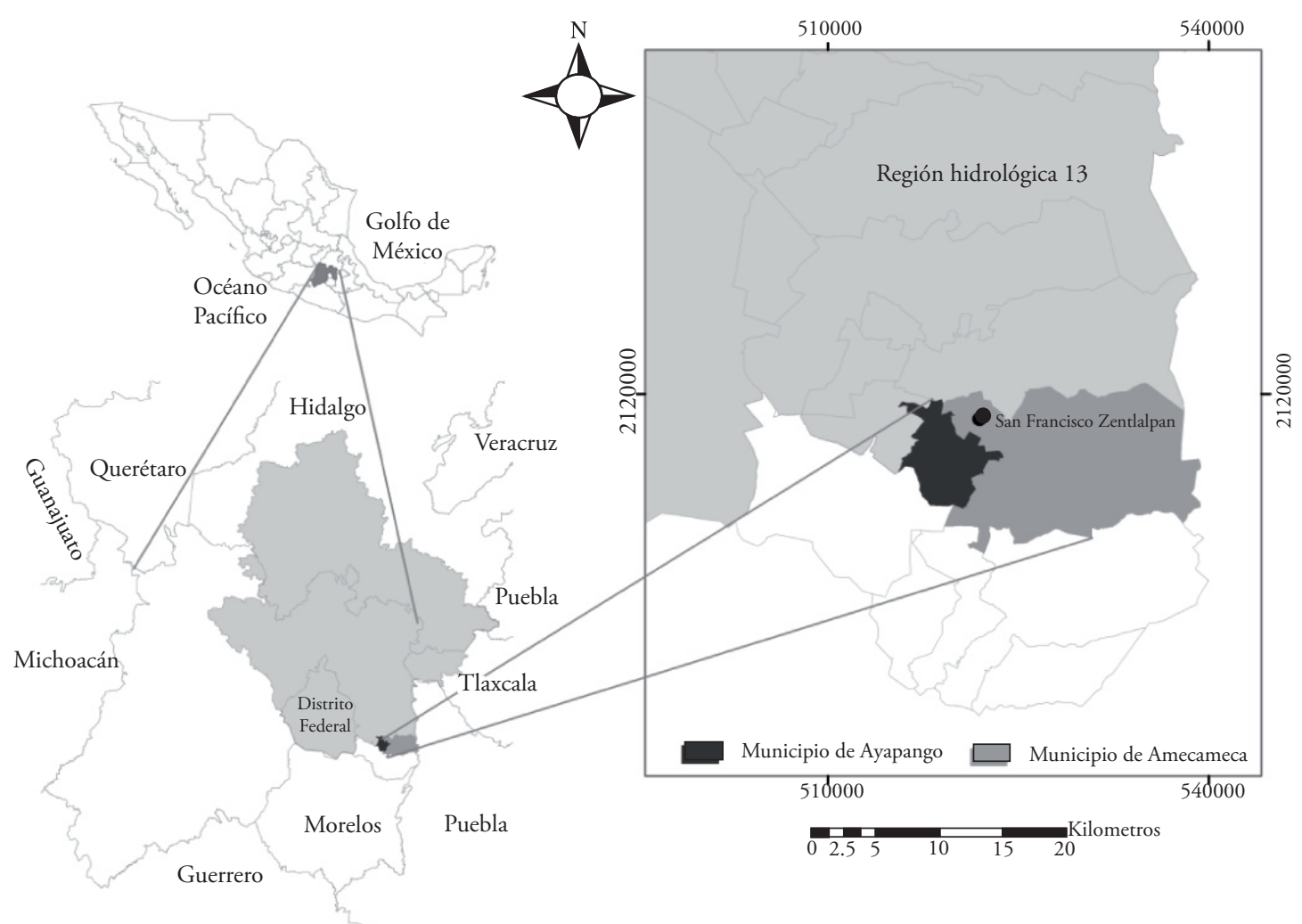

Fuente: elaboración propia. $\bullet$ Source: authors' elaboration.

Figura 1. Localización de la Subcuenca Amecameca, Estado de México.

Figure 1. Location of the Amecameca Sub-Basin, Estado de México.

-GWP (2008) y modificada por Díaz et al. (2009), que incluye un ciclo con siete etapas: (1) Inicio, (2) Visión, (3) Análisis, (4) Estrategias, (5) Plan, (6) Implementación y (7) Evaluación. Tomando en cuenta que esta metodología se enfoca principalmente a aspectos socio-políticos para establecer planes que apoyen las políticas públicas en torno al agua, en este trabajo se realizó una modificación a la metodología para alcanzar el objetivo de esta investigación, por lo que no incluye la elaboración de un plan, sino únicamente la identificación y análisis de la gestión hídrica en el sistema de producción de leche en pequeña escala. Dicha modificación consiste en dos aspectos prioritarios: (a) en lugar de aplicar las estrategias (correspondiente a la etapa cuatro) se implementó una identificación de las dinámicas de los flujos de agua; y (b) se incluyó un análisis regresivo, es decir, primero se identifican las dinámicas ("estrategias") y posteriormente se realizó el análisis. Por lo tanto, se consideraron solo tres de las siete etapas: (1) Visión, (2) Dinámica y (3) Análisis. a change in the methodology was made to reach the objective of this research, so the elaboration of a plan is not included, but rather only the identification and analysis of water management in the small-scale dairy production system. This change consists in two priority aspects: (a) instead of applying the strategies (corresponding to stage four), the dynamics of water flows were identified; and (b) a regressive analysis was included, that is, first the dynamics ("strategies") were identified and then the analysis was performed. Therefore, only three of the seven stages were considered: (1) Vision, (2) Dynamic and (3) Analysis.

Stage 1. Vision. It allowed characterizing the current situation of the sub-basin; that is, the origin, availability, amount and uses of water, and the average annual fee for water in the domestic service block of the municipal tap. This stage included a revision of literature and interviews that were carried out with questions directed at six key informants in the Amecameca Sub-Basin; among them, officials who belonged to: the National Water Commission 
Etapa 1. Visión. Permitió caracterizar la situación actual de la subcuenca; es decir, el origen, disponibilidad, cantidad, usos del agua y la tarifa anual promedio del agua en bloque del servicio doméstico de toma municipal. Esta etapa incluyó una revisión documental y se llevó a entrevista con preguntas guiadas a seis informantes clave de la Subcuenca Amecameca; entre ellos, funcionarios pertenecientes a: la Comisión Nacional del Agua (CONAGUA), la Residencia de Operación Chalco-Sureste de la Comisión de Agua del Estado de México (CAEM), Agua y Saneamiento de Amecameca, la Sexta Regiduría (Comisión de agua, drenaje y alcantarillado) del municipio de Ayapango, la Comisión de Cuenca de los Ríos Amecameca, y la Compañía y la Presidencia del Comité de Cuenca de la Delegación de San Francisco Zentlalpan del municipio de Amecameca.

Etapa 2. Dinámica. Ayudó a identificar los flujos del agua en el sistema familiar de leche. Para esta etapa se generó información en la población objetivo (22 unidades de producción) a través de una encuesta semiestructurada. El tamaño de la muestra se determinó a partir de la ecuación referida en Daniel (2005), considerando el censo realizado por Puente et al. (2011), quienes mencionan que existen 193 unidades de producción en los municipios de Amecameca y Ayapango. En esta etapa se determinaron principalmente dos flujos o consumos y usos del agua: para abrevar y para la limpieza. Se consideraron otros factores, como el costo anual promedio del servicio de toma de agua municipal. El consumo de agua para abrevar se cuantificó a través del volumen en litros que ingirieron los vientres bovinos por cada bebedero durante 24 horas; se identificaron los bebederos en cada unidad de producción, se calculó el volumen de los depósitos y éstos se llenaron un día antes de la cuantificación. La diferencia entre la medición inicial y la final fue la cantidad de agua consumida, la cual se dividió entre el número de vientres de la unidad. El uso de agua de limpieza se cuantificó en función del tipo de ordeño (mecánico o manual), el lavado de máquina, de ubre y el número de utensilios (botes, cubetas, trapos, coladeras, cepillos, etcétera) manejados en la ordeña. Se determinaron los litros de agua o volúmenes utilizados para el lavado de utensilios o maquinaria de forma manual según la capacidad de cada recipiente; es decir, se calculó el tiempo en que se llenaba una
(Comision Nacional del Agua, CONAGUA), the Chalco-Sureste Operation Residency of the Water Commission in Estado de México (Comisión de Agua del Estado de México, CAEM), the Amecameca Water and Sanitation, the Sixth Manager (Water, drainage and sewage commission) of the municipality of Ayapango, the Basin Commission of the Amecameca Rivers, and the Company and Presidency of the Basin Committee in the San Francisco Zentlalpan Delegation, municipality of Amecameca.

Stage 2. Dynamic. It helped to identify the water flows in the family dairy system. For this stage, information in the target population was generated (22 production units) through a semi-structured survey. The size of the sample was determined from the equation referred in Daniel (2005), considering the census carried out by Puente et al. (2011), who mention that there are 193 production units in the municipalities of Amecameca and Ayapango. In this stage two main flows or consumptions and uses of water were determined: to water animals and for cleaning. Other factors were considered, such as the average annual cost of the service from the municipal water tap. The water consumption to water animals was quantified through the volume in liters that bovine heads of breeding stock ingested, from each trough during 24 hours; the water troughs in each production unit were identified, the volume of deposits was calculated, and they were filled up one day before quantification. The difference between the initial measurement and the final one was the amount of water consumed, which was divided by the number of heads of breeding stock in the unit. The use of cleaning water was quantified in function of the type of milking (mechanical or manual), the machine and udder wash, and the number of utensils (cans, pails, cloths, strainers, brushes, etc.) used during milking. The liters or volumes of water used for washing utensils and machinery manually were determined, based on the capacity of each recipient; that is, the time that a 20-liter pail took to fill was calculated (44 seconds), and the time destined to cleaning activities was timed.

Stage 3. Analysis. It consisted of examining integrally the factors that intervened or interacted in the two prior stages (Vision and Dynamic), both at the sub-basin level and the dairy production system, with the goal of determining the way in which the volume of water consumed-used per liter of milk 
cubeta de 20 litros (44 segundos) y se cronometró el tiempo destinado a las actividades de limpieza.

Etapa 3. Análisis. Consistió en examinar de manera integral los factores que intervinieron o interactuaron en las dos etapas anteriores (Visión y Dinámica), tanto a nivel de subcuenca y del sistema de producción de leche, con la finalidad de determinar la forma en que influye el volumen de agua consumida-utilizada por litro de leche producido en la disponibilidad total del agua dentro de la subcuenca. Es decir, analizar si la producción de leche en pequeña escala ejerce o no presión en el recurso agua y, por ende, en la gestión hídrica.

\section{Resultados y Discusión}

Los dos primeros apartados ("Contexto local" y "Fuentes de abastecimiento, disponibilidad y distribución de agua") corresponden a la primera etapa "Visión". El tercer apartado ("Consumo de agua dentro del sistema familiar lácteo") pertenece a la segunda etapa "Dinámica" y el cuarto apartado ("Gestión integrada del agua en el sistema familiar lácteo”), a la etapa "Análisis" de la metodología de análisis utilizada.

\section{Contexto local}

Los actores que administran el recurso agua en los municipios de Amecameca y Ayapango son: servidores públicos a nivel estatal de la Comisión de Agua del Estado de México (CAEM) y servidores municipales (Organismo Público Descentralizado de Agua y Saneamiento de Amecameca y de la $6^{\circ}$ Regiduría con la Comisión de Agua y Alcantarillado del Municipio de Ayapango). Los municipios se encargan de cobrar cuotas, reparar fugas, y del tandeo del recurso hídrico por bloque, entre otras funciones. En la delegación de San Francisco Zentlalpan, municipio de Amecameca, existe un comité de administración del agua que se integra por un presidente, un secretario y un tesorero pertenecientes al equipo de trabajo del delegado municipal (Rueda et al., 2013). El $45 \%$ de las unidades de producción estudiadas reconocieron la existencia del comité, el cual se cambia cada tres años y se encarga de fijar las cuotas para el pago directamente al municipio, el agrupamiento de pobladores para la realización de faenas de limpieza, la reparación de fugas y el tandeo del recurso hídrico (a través de la apertura influences the total availability of water in the subbasin. That is, analyzing whether small-scale milk production exerts pressure or not on the water resource and, therefore, on water management.

\section{Results AND Discussion}

The first two sections ("Local context" and "Sources of water supply, availability and distribution") correspond to the first stage, "Vision". The third section ("Water consumption in the family dairy system") belongs to the second stage, "Dynamic", and the fourth section ("Integrated water management in the family dairy system") to the stage "Analysis", from the analysis methodology used.

\section{Local context}

The actors who manage the water resource in the municipalities of Amecameca and Ayapango are: public servants at the state level from the Water Commission in Estado de México (CAEM) and municipal officers (Decentralized Water and Sanitation Public Organism from Amecameca and the Sixth Manager with the Water and Sewage Commission in the Municipality of Ayapango). The municipalities are in charge of charging fees, repairing leaks, block batching water resources, among other functions. In the San Francisco Zentlalpan delegation, municipality of Amecameca, there is a water administration committee that is made up by a president, a secretary and a treasurer that belong to the municipal delegate's work team (Rueda et al., 2013). Of the production units studied, $45 \%$ recognized the existence of the committee, which changes every three years and is in charge of setting the fees for payment directly to the municipality, of the groups of inhabitants for the performance of the tasks of cleaning, repairing leaks, and batching the water resource (through opening different valves that are found in the community). In the case of the Pahuacan delegation in the municipality of Ayapango, the payment for water from domestic taps is performed by residents to the beneficial owners of the lands through which the "ice-melting system" (streams) passes, which supplies water to the delegation (López et al., 2013). 
de las distintas válvulas que se encuentran en la comunidad). En el caso de la delegación de Pahuacan municipio de Ayapango, el pago de agua de las tomas domésticas lo realizan los pobladores a los usufructuarios de las tierras por donde pasa el "sistema de deshielo" (arroyos) que abastece de agua a la delegación (López et al., 2013).

Resultados de las entrevistas a funcionarios de la CAEM y las encuestas aplicadas a la "población objetivo" registran diferencias entre ambos. En el Sistema Familiar Lácteo (SFL) de la Subcuenca Amecameca, el uso doméstico del agua representó $90 \%$ y el uso pecuario, $10 \%$. Según la CAEM, dentro de la subcuenca el uso doméstico constituyó $90 \%$; el pecuario, $8 \%$; agrícola, $0.5 \%$; e industrial, $1.5 \%$. Los costos promedio por el servicio de toma municipal para SFL fueron de $\$ 825.00$ y, según CAEM, de $\$ 1270.00$; el costo del servicio de camiones cisterna fue de $\$ 419.00$ en promedio dentro del SFL, en comparación con lo reportado por CAEM, de \$543.00. A nivel local, dentro del SFL la distribución del recurso es por toma municipal (95\%); en época de escasez, $36 \%$ de los productores se abastecen de agua a través del servicio del camión cisterna. Dentro de este servicio el uso privado representó $81 \%$ y el municipal de $19 \%$, empleando un promedio de cinco camiones-cisterna anuales por unidad de producción. Estos camiones tienen una capacidad de 10000 Litros. La época de escasez del recurso ocurre en los meses de diciembre a mayo, los cuales coinciden con un mayor empleo de camiones cisterna por las unidades de producción, las cuales se encuentran mayormente en las periferias de los municipios por lo que, según CAEM, en los meses de noviembre a diciembre se reporta un aumento en el uso de camiones cisterna por parte de la población de la zona de estudio, con un promedio de 61 vehículos para este periodo.

\section{Fuentes de abastecimiento, disponibilidad y distribución de agua}

Según la CAEM, $60 \%$ del agua proviene de los arroyos de deshielos y $40 \%$ de los pozos profundos. La distribución o cobertura de agua para la población por toma doméstica municipal fue de $90 \%$, pero en época de escasez, $45 \%$ de los habitantes de la zona recurren a su compra en camiones cisterna. En época de lluvias sólo $9 \%$ de los productores recurren a la
Results from the interviews with officials from CAEM and the surveys applied to the "target population" show differences between them. In the family dairy system (FDS) of the Amecameca SubBasin, domestic water use represented $90 \%$ and water use for livestock production, $10 \%$. According to the CAEM, within the sub-basin, domestic use constituted $90 \%$; livestock, $8 \%$; agricultural, $0.5 \%$; and industrial, $1.5 \%$. The average costs for the service from the municipal tap for FDS were $\$ 825.00$ and, according to CAEM, $\$ 1270.00$; the cost for the tank truck service was $\$ 419.00$ in average, within the FDS, in comparison to that reported by the CAEM, of \$543.00. At the local level, inside the FDS the distribution of the resource is through the municipal $\operatorname{tap}(95 \%)$; in times of scarcity, $36 \%$ of the producers obtain water through the tank truck service. Within this service the private use represented $81 \%$ and the municipal $19 \%$, using an average of five tank trucks annually per production unit. These trucks have a capacity of 10000 liters. The scarcity season for the resource occurs in the months of December to May, which coincide with higher use of tank trucks per production unit, which are found mostly in the periphery of the municipalities; this is why, according to CAEM, an increase in the use of tank trucks by the population in the study zone is reported in the months of November to December, with an average of 61 vehicles for this period.

\section{Sources of water supply, availability and distribution}

According to CAEM, $60 \%$ of the water comes from ice-melt streams and $40 \%$ from deep wells. The water distribution of coverage for the population per municipal tap was $90 \%$, but during the scarcity season, $45 \%$ of the inhabitants in the zone resorted to its purchase from tank trucks. In the rainy season only $9 \%$ of the producers resort to harvesting water they deposit in tubs or small tank trucks.

When examining the factors that interact at the level of the Amecameca sub-basin and within the FDS, some factors were identified which influenced the management of the water resource directly or indirectly. There is an irregular distribution of water among municipal townships that are supplied by two or more sources of water extraction, in contrast with the delegations that do have an ice-melt system that 
cosecha de agua que depositan en tinas o en pequeñas cisternas.

Al examinar los factores que interactúan a nivel de la subcuenca Amecameca y dentro del SFL, se identificaron algunos factores que influyeron directa o indirectamente en la gestión del recurso agua. Existe una distribución irregular del agua entre las cabeceras municipales que son abastecidas por dos o más fuentes de extracción de agua, a diferencia de las delegaciones que sólo cuentan con un sistema de deshielo que las suministra y, dependiendo de la época del año, la cantidad de agua que llega a la localidad disminuye. Ante esta problemática, los productores cubren el suministro de agua a través del uso de camiones-cisternas, lo cual también implica un costo. La Comisión Nacional de Fomento a la Vivienda (CONAFOVI) reporta que los servicios a los que las familias de las poblaciones rurales tienen acceso son escasos y tienden a invertir $\$ 200.00$ mensuales en promedio en camiones cisterna (CONAFOVI, 2005). Un ejemplo claro de esto es el gasto de $\$ 2920.00$ anuales en promedio (incluye los costos de toma municipal y de los camiones cisterna) que realiza el SFL de la Subcuenca Amecameca. Según la Comisión de Agua del Estado de México, para la población de la zona de estudio se utilizan 61 camiones cisterna en promedio (equivalentes a 610000 Litros de agua) en los meses de noviembre y diciembre. Esta es una de las cifras que difiere en mayor medida entre lo reportado por la CAEM y los productores encuestados, ya que CAEM considera a todas las viviendas de la zona de estudio y no solamente a las unidades de producción. Los tres principales factores que interactuaron e influyeron en las unidades de producción del SFL en la subcuenca Amecameca fueron los costos de suministro de agua, la forma de distribución del agua (toma doméstica municipal o servicio del camión cisterna) y el tipo de servicio del camión-cisterna privado o municipal, con una tarifa promedio de $\$ 550.00$ y $\$ 350.00$, respectivamente.

López et al. (2013) mencionan que los municipios se encargan de pagar el volumen de agua que fue consumido a la CAEM; entre las funciones que ésta desempeña en los sistemas de agua que están bajo su administración están: limpieza, vigilancia, verificación, ampliación, rehabilitación y mantenimiento de la red hidráulica, así como la asignación del volumen de agua para cada comunidad, según el número de pobladores y la época del año. Para instalar una toma supplies them and the amount of water that reaches the locality decreases depending on the time of the year. In face of this problem, producers cover the water supply through the use of tank trucks, which also implies a cost. The National Commission of Housing Promotion (Comisión Nacional de Fomento a la Vivienda, CONAFOVI) reports that the services to which families in rural populations have access are scarce and that they tend to invest $\$ 200.00$ monthly in average in tank trucks (CONAFOVI, 2005). A clear example of this is the expenditure of $\$ 2920.00$ annually in average (including the costs of the municipal tap and the tank trucks), which the FDS carries out in the Amecameca Sub-Basin. According to the Water Commission in Estado de México, for the population in the study area an average of 61 tank trucks are used (equivalent to 610 000 liters of water), during the months of November to December. This is one of the figures that differs to the greatest degree between what was reported by CAEN and the producers surveyed, since CAEM considers all the households in the study zones and not just the production units. The main factors that interacted and influenced the FDS production units in the Amecameca Sub-Basin were the water supply costs, the manner of water distribution (municipal domestic tap or tank truck service), and the type of service of the tank truck, private or municipal, with an average rate of $\$ 550.00$ and $\$ 350.00$, respectively.

López et al. (2013) mention that the municipalities are in charge of paying the volume of water that was consumed to the CAEM; among the functions that the latter performs in the water systems that are under its administration, there are the following: cleaning, surveillance, verification, extension, rehabilitation and maintenance of the water network, as well as allotment of the water volume for each community, based on the number of residents and the time of year. In order to install a municipal water tap, users choose the drinking water supply based on the classification of domestic or non-domestic use (Rueda et al., 2013). For an equitable payment of the drinking water supply service, non-domestic use is classified in three levels of consumption: dry (establishments that do not have a tap, sink or toilet, and in case of requiring water, it is only for the staff), semi-dry (they require higher consumption, of approximately 15 to $75 \mathrm{~m}^{3}$ bimonthly to perform their activities, in addition to that used by the staff, 
municipal de agua los usuarios elijen el suministro de agua potable de acuerdo con la clasificación de uso doméstico o no doméstico (Rueda et al., 2013). Para un pago equitativo del servicio por el suministro de agua potable el uso no doméstico se clasifica en tres niveles de consumo: seco (establecimientos que no cuentan con llave, lavabo o W.C. y, en caso de requerir agua, ésta es solo para el personal), semiseco (requieren un mayor consumo, de aproximadamente 15 a $75 \mathrm{~m}^{3}$ bimestrales para realizar sus actividades, además de la utilizada por el personal, no mayor a cinco empleados) y húmedo (son aquellos establecimientos que requieren un consumo de 76 a $150 \mathrm{~m}^{3}$ bimestrales para realizar sus actividades). Según la Gaceta del Gobierno del Estado de México (2012), los ranchos y establos se encuentran clasificados dentro del uso húmedo. Sin embargo, como las unidades de producción de leche en pequeña escala (UPLPE) o familiar en el área de estudio se ubican dentro del mismo terreno o propiedad de la vivienda, cuentan con una toma de agua de uso doméstico.

\section{Consumo de agua dentro del sistema familiar lácteo}

Las entrevistas a los 22 productores del SFL permitieron identificar los dos flujos de agua en el sistema de producción: el consumo de agua para bebida y el agua dedicada a servicio de limpieza. Estos valores corresponden a la segunda etapa "Dinámica" de la metodología. El consumo de agua para abrevar que se obtuvo en el SFL de la Subcuenca Amecameca es mayor (5.6 l de agua por L de leche) en comparación con lo reportado por diversos autores (Kume et al., 2010; Kramer et al., 2008; Nosetti et al., 2002 y Meyer et al., 2004) (Cuadro 1), debido a que la or no more than five employees), and humid (they are the establishments that require a consumption of 76 to $150 \mathrm{~m}^{3}$ bimonthly to perform their activities). According to the Gazette of the Estado de México Government (2012), ranches and establishments were classified within the humid use. However, as the small-scale or family dairy production units (SSDPS) in the study area are located within the same terrain or household property, they have one domestic unit water tap.

\section{Water consumption in the family dairy system}

The interviews with 22 FDS producers allowed identifying the two water flows in the production system: water consumption for drinking water and water used for the cleaning service. These values correspond to the second stage "Dynamic" of the methodology. Water consumption for watering animals that was obtained in the FDS of the Amecameca Sub-Basin is higher (5.6 l of water per liter of milk) in comparison with what was reported by various authors (Kume et al., 2010; Kramer et al., 2008; Nosetti et al., 2002; Meyer et al., 2004) (Table 1), because most of the studies reported were carried out with factors and conditions that were totally different than those evaluated in this research; for example, geographic region, milk production systems, type of diet, irrigation to obtain fodder, period of lactation, physiological stage, climate, season of the year, among others. The value obtained in this study represents more than double what was reported by Kume et al. (2010), with a value of 2.66 liters of water per liter of milk per bovine head of breeding stock. This work was carried out in Japan with lactating and dry cows and, with

Cuadro 1. Comparativo de consumo promedio de agua en diferentes sistemas de producción láctea.

Table 1. Comparative analysis of the average water consumption in different dairy production systems.

\begin{tabular}{|c|c|c|}
\hline Referencia & $\begin{array}{l}\text { Consumo voluntario de agua de bebida por } \\
\text { vaca (L agua/L leche) }\end{array}$ & Uso de agua de servicio por vaca \\
\hline$\overline{\text { Kramer } \text { et al. (2008) }}$ & 2.36 & \\
\hline Kume et al. (2010) & 2.66 & \\
\hline Sánchez (1965) & & $9.60 \mathrm{l}$ agua/vaca \\
\hline Meyer et al. (2004) & 2.62 & \\
\hline Nosetti et al. (2002) & & $0.95 \mathrm{l}$ agua/ vaca \\
\hline Spörndly E. y E.Wredle (2005) & 1.94 & \\
\hline Valores obtenidos & 5.60 & $1.00 \mathrm{l}$ agua/ $1 \mathrm{de}$ leche \\
\hline
\end{tabular}

Fuente: elaboración propia. • Source: authors’ elaboration. 
mayoría de los estudios reportados fueron realizados con factores y condiciones totalmente distintas a las evaluadas en esta investigación; por ejemplo, región geográfica, sistemas de producción de leche, tipo de dieta, el riego para obtención de forrajes, periodo de lactancia, etapa fisiológica, clima, época del año, entre otras. El valor obtenido en este estudio representa más del doble de lo reportado por Kume et al. (2010), con un valor de 2.66 litros de agua por litro de leche por vientre bovino. Dicho trabajo se realizó en Japón con vacas lactantes y secas, con una producción promedio de 29.51 por día de leche. En el SFL de la Subcuenca Amecameca se identificó que las unidades de producción cuentan con ocho vacas lactantes en promedio, con una producción de $15 \mathrm{l}$ de leche/vaca/día y un consumo de "agua para abrevar" promedio de 84 litros de agua/día/vaca lactante, sin considerar el "agua de limpieza".

Respecto al agua de limpieza, en el SFL de la Subcuenca Amecameca se identificó que se requiere un litro de agua para producir un litro de leche. Por su parte, Nosetti et al. (2002) reportan 0.95 litros de agua por litro de leche por vaca para la limpieza de la ubre, bajo un sistema especializado con vacas lactantes en Argentina. En sus estadísticas sobre producción de leche, la CANILEC (2013) reporta que a nivel nacional se necesitan 300 litros de agua por litro leche en la producción tecnificada para bebederos, lavado de instalaciones, riego de granos y forrajes, entre otros factores.

La población total en los municipios de Amecameca y Ayapango es de 57285 habitantes (IGECEM, $2011 \mathrm{a}, \mathrm{b})$, los cuales según Burns (2011) consumen para uso público urbano $83.7 \%$ del volumen total de agua concesionada para ambos municipios. A partir del valor obtenido en este estudio, de 6.6 litros de agua por litro leche, y multiplicándolo por el volumen de producción de leche, se obtuvo la cantidad de agua que se consume en el SFL de la Subcuenca Amecameca (Cuadro 2). Asimismo, a partir del volumen total de agua concesionada para cada municipio, se estimó el porcentaje de agua utilizada para la producción láctea respecto al total; dicho porcentaje representa el impacto que ejerce el sistema productor lácteo sobre la disponibilidad del recurso hídrico en la subcuenca.

Considerando que el volumen de producción de leche en el municipio de Amecameca es mayor con respecto al de Ayapango, el volumen de agua utilizado en el SFL también es superior. Sin embargo, el porcentaje de agua utilizada en el SFL respecto al an average production of 29.51 of milk per day. In the Amecameca Sub-Basin FDS, it was found that production units have eight lactating cows in average, with a production of $151 \mathrm{of}$ milk/cow/day and a consumption of average "watering water" of 84 liters of water/day/lactating cow, without taking into consideration the "cleaning water".

With regard to the cleaning water, in the Amecameca Sub-Basin FDS it was identified that one liter of water is required to produce a liter of milk. In turn, Nosetti et al. (2002) reported 0.95 liters of water per liter of milk per cow to clean the udder, under a specialized system with lactating cows in Argentina. In its statistics about milk production, CANILEC (2013) reported that 300 liters of water are needed at the national level per liter of milk in mechanized production, for drinking troughs, washing the facilities, irrigating grains and fodder, among other factors.

The total population in the municipalities of Amecameca and Ayapango is 57285 inhabitants (IGECEM, 2011a, b), who, according to Burns (2011), consume for urban public use $83.7 \%$ of the total volume of water granted in concession for both municipalities. Stemming from the value obtained in this study, of 6.6 liters of water per liter of milk, and multiplied by the volume of milk production, the amount of water that is consumed in the Amecameca Sub-Basin FDS was obtained (Table 2). Likewise, stemming from the total volume of water granted in concession for each municipality, the percentage of water used for milk production was estimated with regard to the total; this percentage represents the impact that the dairy production system exerts on the availability of the water resource in the sub-basin.

Considering that the milk production volume in the municipality of Amecameca is higher compared to that of Ayapango, the volume of water used by the FDS was also higher. However, the percentage of water used in the FDS compared to the total volume of water granted in concession at the municipal level is higher in Ayapango (1.49\%) than in Amecameca $(0.71 \%)$. In both cases, the percentage of water used does not represent $3 \%$ of the total volume; however, this doesn't mean that practices cannot be implemented to improve management of the water resource, both for "water for consumption" and for "water for cleaning" in 
Cuadro 2. Porcentaje de agua utilizada en la producción láctea respecto al volumen concesionado de agua en los municipios de Amecameca y Ayapango.

Table 2. Percentage of water used in dairy production in relation to the volume of water granted in concession in the municipalities of Amecameca and Ayapango.

\begin{tabular}{llrrr}
\hline Municipio & 1 leche/año & 1 agua/año & 1 agua/l leche & \\
\hline Amecameca & 3400340.0 & 3153600000.0 & 22442244.0 & 0.71 \\
Ayapango & 1162415.5 & 511829280.0 & 7671942.3 & 1.49 \\
\hline Total & 4562755.5 & 3665429280.0 & 30114186.3 & 2.20 \\
\hline
\end{tabular}

Fuente: elaboración propia con información obtenida en trabajo de campo (6.6 l agua / 1 leche), (Puente et al., 2011). \ Source: authors' elaboration with information obtained during field work (6.6 l water / 1 milk), (Puente et al., 2011).

volumen total de agua concesionada a nivel municipal es mayor en Ayapango (1.49 \%) que en Amecameca $(0.71 \%)$. En ambos casos el porcentaje de agua utilizada no representa $3 \%$ del volumen total; aunque esto no significa que no se puedan implementar prácticas para mejorar el manejo del recurso agua, tanto para el "agua para consumo" como para el "agua de limpieza" en el SFL en la Subcuenca Amecameca, con la finalidad de realizar un uso y manejo sustentable del recurso.

\section{Gestión integrada del agua en el sistema familiar lácteo}

Respecto al porcentaje de agua (menor a $3 \%$ ) utilizado en el SFL en los municipios de Amecameca y Ayapango, y del cual se genera un impacto mínimo, éste podría aumentar con el paso del tiempo debido a factores externos, como el cambio climático que altera el ciclo hidrológico (UNESCO, 2010). En este sentido, Steinfeld et al. (2009) prevén que el consumo de agua por parte de la ganadería aumentará $50 \%$ y, por consiguiente, su impacto también.

La disponibilidad y la distribución de agua son factores que influyen en la gestión hídrica del recurso. La disponibilidad se relacionó de forma directa con la época del año en la que se capta el recurso, es decir, la temporada de lluvia, impactando en la distribución del agua entre las zonas céntricas (cabeceras municipales) con mayor distribución y frecuencia del recurso, a diferencia de las periferias de las comunidades (delegaciones). La distribución también está determinada por el tipo de servicio del camión-cisterna (privado o municipal) que se utilizó para satisfacer las necesidades hídricas del sistema, ya que la tarifa que genera cada servicio es diferente. El utilizar el servicio de camiones-cisterna, especialmente en la época de estiaje, representó un costo económico adicional para las unidades de producción. the Amecameca Sub-Basin FDS, with the aim of performing a sustainable use and management of the resource.

\section{Integrated management of water in the family dairy system}

With regard to the water percentage (less than $3 \%$ ) used in the FDS in the municipalities of Amecameca and Ayapango, and of which there is a minimal impact, it could increase with the passage of time due to external factors, such as climate change, that alter the water cycle (UNESCO, 2010). In this sense, Steinfeld et al. (2009) foresee that the water consumption by livestock production will increase in $50 \%$ and, therefore, its impact also.

The availability and distribution of water are factors that influence management of the water resource. The availability was directly related with the time of year when the resource is captured, that is, the rainy season, impacting the water distribution between the central zones (municipal townships), with greater distribution and frequency of the resource, in contrast with the periphery of the communities (delegations). The distribution is also determined by the type of service of the tank truck (private or municipal) that was used to satisfy the water needs of the system, since the fee each service generates is different. Using the tank truck service, especially during drought season, represented an additional economic cost for the production units.

The actors who intervene in water administration in the Amecameca Sub-Basin play an important role, from the ones that are legally duly established (state and municipal) to the ones who participate with an honorary position, as well as the ejido authorities who provide a service to their community. 
Los actores que intervienen en la administración del agua en la Subcuenca Amecameca juegan un papel importante; desde los que se encuentran debidamente establecidos jurídicamente (estatales y municipales) hasta los que participan con un cargo honorífico, así como las autoridades ejidales para brindar un servicio a su comunidad.

\section{ConClusiones}

Diversos factores influyen en la gestión hídrica y en el sistema de producción de leche en pequeña escala, destacando la disponibilidad y la distribución de agua (toma doméstica municipal o camión-cisterna), tipo de servicio del camión cisterna (privado o público), monto económico del suministro de agua, y la época de estiaje. Bajo estas condiciones de manejo del recurso agua y el volumen total de producción de leche en la Subcuenca Amecameca, se determinaron los niveles de consumo de agua (para consumo y limpieza) necesarios para producir un litro de leche, que fue de 6.6 litros de agua (para consumo y limpieza) por un litro de leche producida. Esta cantidad de líquido requerido para producir un litro de leche en las unidades de producción del Sistema Familiar de Leche (SFL) es mayor a los parámetros reportados por otros autores citados en este estudio. Respecto al agua para abrevar, el valor obtenido en este estudio fue menor y más eficiente.

Se enfatiza que el SFL ejerce una presión mínima (no mayor de $3 \%$ ) respecto al consumo total de agua a nivel municipal.

Se destaca que los administradores del recurso hídrico (estatales, municipales, delegacionales y ejidales) solo ejercen las funciones de suministrar agua, reparar y mantener la infraestructura, pero no contemplan el papel de conservarlo sustentablemente.

Con base en la aplicación de la metodología modificada del enfoque GIRH, en la zona de estudio no hay un problema de escasez en el volumen de agua concesionada, sino más bien en lo que respecta a la distribución del líquido.

\section{SugERENCIAS}

Se recomienda que las políticas públicas tomen en consideración la presión que ejerce el sector pecuario sobre el recurso hídrico, ya que permitirá una mejor visión del contexto actual del agua con la finalidad de lograr una mejor administración, distribución y

\section{Conclusions}

Various factors influence water management and the small-scale milk production system, with the availability and distribution of water (municipal domestic tap or tank truck), type of service of the tank truck (private or public), economic amount of the water supply, and drought season standing out. Under these conditions of management of the water resource and the total volume of milk production in the Amecameca Sub-Basin, the levels of water consumption needed to produce one liter of milk were determined (for consumption and cleaning), which were 6.6 liters of water (for consumption and cleaning) per liter of milk produced. This amount of liquid required to produce a liter of milk in the Family Dairy System (FDS) production units is higher than the parameters reported by other authors cited in this study. With regard to watering water, the value obtained in this study was lower and more efficient.

It is emphasized that the FDS exerts a minimal pressure (no higher than $3 \%$ ) with regard to the total water consumption at the municipal level.

It is highlighted that the administrators of the water resource (state, municipal, delegation and ejido) only exercise the functions of supplying water, repairing and maintaining the infrastructure, but they do not contemplate the role of conserving it in a sustainable manner.

Based on the application of the modified methodology from the IWRM approach, in the study zone a problem of scarcity in the volume of water granted in concession was not found, but rather in relation to the distribution of the liquid.

\section{SuggeSTIONS}

It is recommended that public policies take into consideration the pressure that the livestock production sector exerts on the water resource, since it will allow a better view of the current context of water, with the aim of achieving a better administration, distribution and sustainable use of the resource. It is also suggested to continue performing research around the water resource and the sustainability of milk production in the region, such as determining the water consumption needed for cheese production 
uso sustentables del recurso. También se sugiere seguir realizando investigaciones en torno al recurso agua y a la sustentabilidad de la producción lechera en la región, tales como determinar el consumo de agua necesaria dentro de la producción quesera y el destino final de esta agua, a fin de realizar propuestas que permitan llegar a la sustentabilidad en esta actividad. Asimismo, se hace necesario impulsar estrategias encaminadas a la cosecha de agua de lluvia, ya que ello permitiría liberarla para actividades humanas, aumentar el número de hatos sin afectar el volumen de agua concesionada, además de reducir costos de producción al no consumir agua de pipas.

Entre más eficiente sea la gestión del agua, más fácil será visualizar un mejor futuro en el suministro para las próximas generaciones de la zona y las diferentes actividades productivas, entre ellas la producción láctea. La administración por las comunidades es importante, ya que ellas saben claramente cuáles son las necesidades de la comunidad.

\section{Agradecimientos}

La presente investigación forma parte del megaproyecto "Evaluación de la Sustentabilidad de los Sistemas de Producción en Pequeña Escala" con apoyo del CONACYT 129449. Al CONACYT por la beca otorgada a la Mtra. Laura Dolores Rueda Quiroz para la realización del posgrado en Ciencias Agropecuarias y Recursos Naturales. Al Centro Universitario UAEM Amecameca de la Universidad Autónoma del Estado de México. A los funcionarios de las autoridades federales, estatales y municipales y, en especial, a los productores de leche de la Subcuenca Amecameca que participaron en este estudio.

\section{Literatura Citada}

Aguilar, A. 2009. Innovación en la gestión de los recursos hídricos en Hidalgo. Tesis de Doctorado en Hidrociencias. México. Colegio de Posgraduados.

Berghuber, K., C. Vogl, y S. Gramajo. 2010. Conocimientos, costumbres y estrategias de la gestión del agua en el caserío Vista Hermosa del Departamento San Marcos, Guatemala. Agricultura, Sociedad y Desarrollo Vol.7 No.1: 81-107.

Burns, E. 2009. Repensar la cuenca. La gestión de ciclos del agua en el Valle de México. Universidad Autónoma Metropolitana. México.

Burns, E. (coord). 2011. Plan Hídrico para las Subcuencas Amecameca, la Compañía y Tláhuac Xico. Universidad Autónoma Metropolitana y Comisión de cuenca de los ríos Amecameca y la Compañía. México and the final destination of this water, so as to carry out proposals that allow attaining sustainability in this activity. Likewise, it is necessary to foster strategies directed at the harvest of rain water, since this would allow liberating it for human activities, increasing the number of herds without affecting the volume of water granted in concession, in addition to reducing production costs by ceasing to consume water tanks.

The more efficient the water management becomes, the easier it will be to visualize a better future in the supply for the next generations in the zone and the different productive activities, among them milk production. Management by communities is important, since they know clearly what their needs are.

\section{Aknowledgements}

This research is part of the mega-project "Evaluation of Sustainability of the Small-Scale Production Systems" with the support of CONACYT 129449. To CONACYT for the scholarship granted to Laura Dolores Rueda Quiroz to perform graduate studies in Agricultural Sciences and Natural Resources. To the federal, state and municipal authorities and, in particular, the milk producers in the Amecameca Sub-Basin who participated in this study.

- End of the English version -

Carabias, J., y R. Landa. 2005. “Agua, Medio Ambiente y Sociedad: Hacia la Gestión Integral de los Recursos Hídricos en México". Ed. UNAM, Colegio de México, Fundación Gonzalo Río Arronte. México. D.F.

Carbajal, J. E., H. Campos, y J. R. Calderón. 2011. Políticas de conservación y manejo del agua en el Estado de México, caso: "Santuario del agua Valle de Bravo". Quivera. No. 2011-2: 63-92.

CANILEC. 2013. Estadísticas/Producción Láctea. Consultado en: www.canilec.org.mx/prod_leche.html

CONAFOVI. 2005. Guía para el uso eficiente del agua en desarrollos habitacionales. CONAFOVI. México, D. F.

CONAGUA. 2006. Foro Mundial del Agua. Comisión Nacional del Agua. México, D. F.

CONAGUA. 2009. Estadísticas del Agua de la Región Hidrológico-Administrativa XIII, Aguas del Valle de México. Primera Edición. Comisión Nacional del Agua, Secretaría de Medio Ambiente y Recursos Naturales, Coyoacán, México, D.F. Consultado en: www.conagua.gob.mx .

CONAGUA. 2014. Programa Nacional Hídrico 2014-2018. Secretaría de Medio Ambiente y Recursos Naturales. México, D. F.

Daniel, W. 2005. Bioestadística. $4^{\circ}$ Edición, Editorial Limusa, Madrid, España. 
Díaz, C., A. M. Esteller, C. A. Velasco, V. J. Martínez, J. C. Arriaga, F. A. Vilchis, S. L. Manzano, M. L. Colín, J. S. Miranda, C. M. Uribe, y H. A. Peña. 2009. Guía de Planeación Estratégica Participativa para la Gestión Integrada de los Recursos Hídricos de la Cuenca Lerma-Chapala-Santiago, Capítulo Estado de México, Red Interinstitucional e Interdisciplinaria de Investigación, Consulta y Coordinación Científica para la Recuperación de la Cuenca, 1era. Edición, México.

Espinosa, A. E. 2009. La Competitividad del Sistema Agroalimentario Localizado Productor de Quesos Tradicionales, Tesis de Doctorado en Ciencias Agropecuarias y Recursos Naturales. Universidad Autónoma del Estado de México.

FAO. 2010. Ganadería Bovina en América Latina: Escenario 2008-2009 y Tendencias del Sector, FAO, Santiago de Chile, Consultado en: www.rlc.fao.org/es/ganaderia/pdf/ganbov. pdf.

Gaceta del Gobierno del Estado de México. 2012. Tarifas para red de distribución de agua potable para el municipio de Amecameca. Comisión de agua del Estado de México. Diciembre.

Gallardo, N. 2004. Situación actual de la producción de leche de bovino en México. Coordinación General de Ganadería. SAGARPA. México.

GWP (Global Water Partnership). 2003. Integrated Water Resources Management Toolbox, Version Stockholm: GWP Secretariat.

GWP (Global Water Partnership). 2008. Principios de Gestión Integrada de los Recursos Hídricos. Bases para el Desarrollo de Planes Nacionales. GWP (Global Water Partnership) Centro y Sudamérica. Edit. Elanders. Brasil.

GWP-INBO. 2009. Manual para la Gestión Integrada de los Recursos Hídricos. GWP (Global Water Partnership) e INBO (International Network of Basin Organizations, INBO). Paris, Francia.

IGECEM. 2011a. Estadística Básica Municipal del Estado de México. Municipio de Ayapango. Gobierno del Estado de México. México.

IGECEM. 2011b. Estadística Básica Municipal del Estado de México. Municipio de Amecameca. Gobierno del Estado de México. México.

Kramer, E., E. Stamer, J. Spilke, y J. Krieter. 2008. Analysis of water intake, dry matter intake and daily milk yield using different error covariance structures. Vol. 2 No.11: 15851594.

Kume, S. A, K. B. Nonaka, T. C. Oshita, y C. Kozakai. 2010. Evaluation of drinking water intake, feed water intake and total water intake in dry and lactating cows fed silages. Livestock Science.Vol.128: 46-51

López, S., S. Martínez, y J. Palerm. 2013. Las comunidades en la administración de sistemas de agua potable: región de los volcanes, Estado de México. Agricultura, Sociedad y Desarrollo. Vol. 10, No.1: 39-58.

Meyer, U., M. Everinghoff, D. Gädeken, y G. Flachowsky. 2004. Investigations on the water intake of lactating dairy cows. Livestock Production Science. Vol. 90: 117-121
Nosetti, L., M. A. Herrero, M. Pol, M. V. Maldonado, M.S. Iramain, y M. Flores. 2002. Cuantificación y caracterización de agua y efluentes en establecimientos lecheros. 1 Demanda de agua y manejo de efluentes. Revista InVet. Vol. 4 (1): 37-43.

Puente, J., P. L. Brunett, A. E. Espinosa, y M. Márquez. 2011. Cálculo del consumo de energía en la producción de leche en pequeña escala. In: Cavalloti, B.; B. Ramírez; F. Martínez; C. Marcof. A. Cesín. La ganadería ante el agotamiento de los paradigmas dominantes. Chapingo, México. Universidad Autónoma Chapingo. Vol. 1. pp: 201-210.

Rueda, Q. L. D., P. L. Brunett, A. E. Espinosa, y R. T. T. Arteaga. 2013. Caracterización de la gestión del agua en el sistema de producción de leche en pequeña escala, en la subcuenca de Amecameca, Estado de México. In: Cavalloti, B., B. Ramírez, A. Cesín, G. Rojo, y C. Marcof. 2013. Seguridad Alimentaria y Producción Ganadera en Unidades Campesinas. Chapingo, México. Universidad Autónoma Chapingo. Vol. 1. pp: $260-271$

Sánchez, D. 1965. El ganado lechero y las industrias lácteas. Edit. Limusa, lera edición, México, D.F.

SAGARPA. 2000. Claridades Agropecuarias. Enero Vol. 1 México, D.F.

SEMARNAT-CONAGUA. 2012. Programa de Saneamiento Integral de la Parte Alta de la Cuenca del Río Amecameca. Gobierno Federal. Amecameca, Estado de México, México. Consulta en: www.conagua.gob.mx.

SIAP. 2006. Producción de leche de bovino a nivel nacional periodo 1996-2006. Consulta en: www.siap.gob.mx

Soares, D. 2007. Crónica de un fracaso anunciado: la descentralización en la gestión del agua potable en México. Agricultura, Sociedad y Desarrollo. Vol. 4, No.1: 19-37.

Solanes M., y F. Gonzalez. 1996. Los principios de Dublin reflejados en una evaluación comparativa de ordenamientos institucionales y legales para una gestión integrada del agua. Asociación Mundial por el Agua (GWP, Global Water Partnership). Namibia.

Spörndly, E., y E. Wredle. 2005. Automatic Milking and Grazing-Effects of Drinking Water location of water intake, milk production and Cow. Behavior. Journal of Dairy Science. Vol. 88, No. 5: 1711-1722.

Steiner, G. A. 1998. Planificación Estratégica, Lo que Todo Director debe Saber. Vigésima Tercera Reimpresión. Editorial CECSA.

Steinfeld, H., P. Gerber, T. Wassenaar, V. Castel, M. Rosales, y C. De Haan. 2009. Problemas ambientales y opciones, La Larga sombra del Ganado, FAO, Roma.

UNESCO. 2010. El agua en un mundo en cambio. 3er. Informe de las Naciones Unidas sobre el desarrollo de los recursos hídricos en el mundo. Programa Mundial de Evaluación de los Recursos Hídricos. Sevilla, España.

Villanueva, M. 2008. Microcuencas y campesinos. $1^{\circ}$ Edición, Universidad Autónoma Metropolitana, México. 